\title{
Turn of the century architecture in Transylvania, Romania and its influences from the architecture of Hungary
}

\author{
M. Bostenaru Dan \\ "Ion Mincu" University of Architecture and Urbanism, Bucharest and \\ Foundation ERGOROM '99, Bucharest, Romania
}

\begin{abstract}
A common feature of turn-of-the-century architecture in Hungary was the innovation in the façades, but there was innovation in the use of construction materials as well. István Medgyaszay promoted the introduction of a special form language to do justice to the employment of reinforced concrete. The architect not only conducted theoretical discourse, but also put into practice these thoughts in buildings like the theatre in Veszprém, Hungary. Other buildings use a form language adequate for reinforced concrete, such as the multi-story block of flats on Népszinház Street, Budapest, Hungary, by the architect Béla Lajta. Such uses of different materials for a form language which would have required reinforced concrete are not singular in the architecture of the time, as other considerations such as material costs or the development of the technique played a role. Numerous architects who studied or worked in Budapest built in Transylvania, now Romania, at the turn-of-the-century. The city most marked by such buildings is Oradea. In Oradea the Moskovits Palace uses for the first time the Hennebique technique with floors out of plates with reinforced concrete nervures. Also, in other cities of Transylvania there are buildings of Hungarian architects, such as Cluj-Napoca or Târgu Mureş. In Cluj-Napoca we remark on the architecture of Károly Kós, whose original architecture involves folk elements and has inspired one of the best known architects of today: Imre Makovecz. Imre Makovecz, in his church from Százhalombatta, found an architectural language between reinforced concrete and timber as it was theoretically described by Medgyaszay.

Keywords: secession, Oradea, Romania, Hungary, early reinforced concrete.
\end{abstract}




\section{Introduction}

Francois Hennebique patented his system in reinforced concrete in 1892. Following this, by Hennebique himself or by other contractors, numerous buildings were done in reinforced concrete. But an architectural language for reinforced concrete started to be looked at with the arrival of the Modern Movement, between the two World Wars. Before, the previous architectural language was maintained, while doing sometimes the structure in reinforced concrete. The innovation was in the language of the façade, and not in the interior partition. The theoretical discourse of structure and shape from the early days of reinforced concrete remains, however, remarkable and influences architecture until today. Such aspects will be analysed in this paper, regarding their employment on the territory of the former Austro-Hungarian monarchy, regarding the spread from the capital to the provinces.

\section{Architecture in Hungary}

The turn of the century in Budapest, the time of the Dual Monarchy, was a time of co-existence of numerous architecture styles. They all strived towards innovation in architecture. The parallel styles were (Moravánszky [1]):

- the precursors such as Frigyes Spiegel (Fig. 1(a)),

- architecture of engineers: Western Railway Station of Gustave Eiffel (Fig. 2(a)),

- Viennaise Secession works such as those of Otto Wagner (Fig. 1b) and Josef Hoffman,

- Secession influence such as the Zoo by Károly Kós, Dezsö Zrumeczky, Kornél Neuschloß-Knüsli (Fig. 2(b)).

- the national style of Ödön Lechner (Fig. 3(a) and (b)) and his successors, in Hungary (Géza Márkus, Fig. 3(c)) or Transylvania (Komor and Jakab),

- innovative use of reinforced concrete,

- national Romanticism: Károly Kós, Aladár Árkay, Béla Lajta (Fig. 4),

- pre-modern Rationalism in façade innovation: Jonás (Fig. 1(c)), Béla Lajta (Fig. 6(a)), József Vágó (Fig. 5(a)), Töry and Pogány (Fig. 5(b)), Málnay and Haász (Fig. 5(c)),

- new concepts for space and volume or in social housing (Málnay and Haász).

The rental house in Isabella Street (Fig. 1(a)) is the first example of non historical architecture in Hungary, built 1897. The polycrom ornaments of sea animals show the influence of Gottfried Semper (Moravánszky [1]).

This synagogue built in 1871 (Fig. 1(b)) is the first religious building of Otto Wagner, who also built the only Art Nouveau church in Vienna. Impressive is the interior space, but the building cannot be measured with his later works.

In case of the Geology museum (Fig. 3(a)), built in 1896-1899, the main characteristics of the style of Ödön Lechner are coming to expression: the role of the subdivision is less important, compared to the big decorated wall surface. 

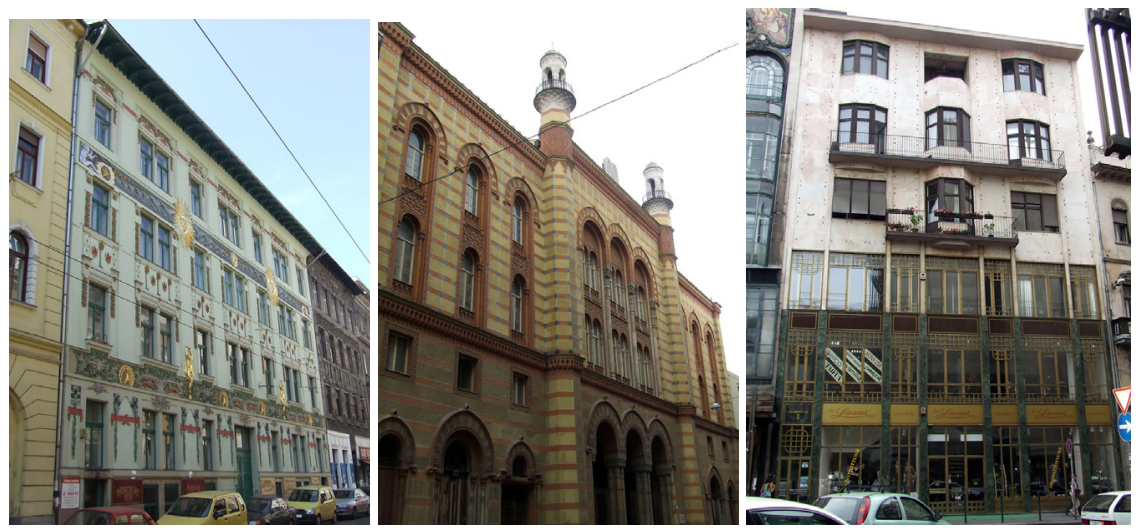

Figure 1: Turn-of-the-century architecture in Budapest: (a) arch. Frigyes Spiegel; (b) arch. Otto Wagner; (c) brothers Jónás.
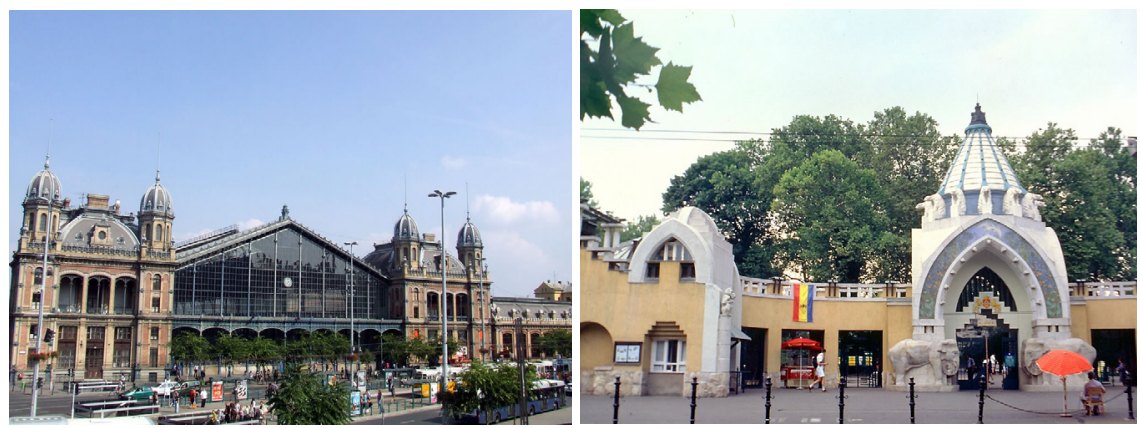

Figure 2: Turn-of-the-century architecture in Budapest: (a) Western Railway Station; (b) entrance to the Zoological Garden.
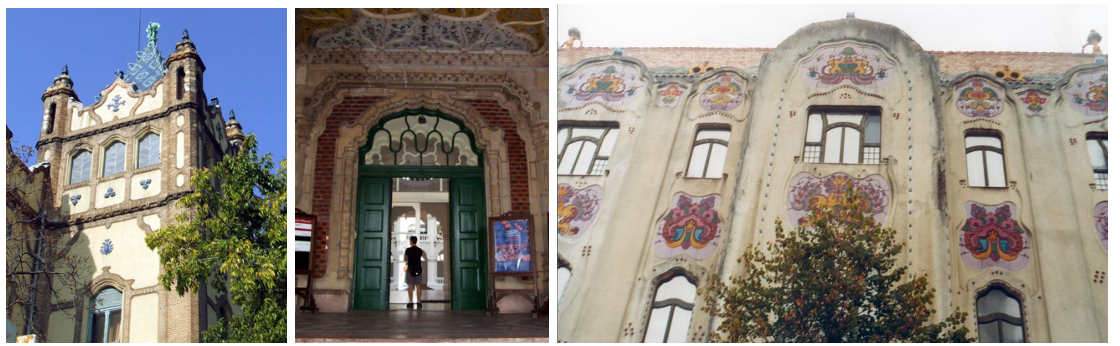

Figure 3: Turn-of-the-century architecture in Hungary: (a) Geology Museum by Ödön Lechner; (b) Arts and Crafts Museum by Ödön Lechner; (c) Géza Markus's Cifra house, Kecskemét.

The plastered façade appears, according to Moravánszky [1], as from a skeleton and infill fields.

The Arts and Crafts Museum (1891-1896, Fig. 3(b)) is a picturesque building with the high, tent-like roof out of coloured, enamelled tiles. Moravánsky [1] 
writes that the oriental art was not totally foreign to the Danube monarchy, since the walls of the Majolica house of Otto Wagner have the same carpet-like decoration, even if the transfer was maybe made possible through the study of Mediterranean cultures (the Doge Palace in Venice is decorated similarly). However, the cornerstones of the characteristics of Lechner's style are given: the composition with a middle resalit, the polychrome treatment of the wall and especially of the roof surfaces, the total dissolution of the classical cornice. Moravánszky [1] notes that in the ground floor solution Lechner remains conservative. What makes the space complex an experience place it the richness in decoration and the connections and views through the spaces.

This commerce school by Béla Lajta was built in 1909-1910 (Fig. 4(a)). It is an example of rationalist architecture before World War I. The volume is partitioned asymmetrically, with two tower-shaped blocks, which close between them the classes and the gathering rooms. The influence of German brick constructions is visible in the façade. The verticality is emphasized. The flat ornaments over the entrances remind popular art, but they are reduced to geometric reliefs and so the building belongs to pre-Modernism [1].

The commerce and dwelling house Rózsavölgyi was built in 1912-1913 (Fig. 4(b)). Lajta develops a new language here, characterised by plainness and elegancy. This is a type of multifunctional building, like the house on Michaeler Platz (1909-11) of Adolf Loos, the Thonet house of Lechner (1888-89) and the Majolica House of Otto Wagner (1898-99) in Vienna. The most important influence has, according to Moravánszky [1], the Artaria House (1902) of Fabiani in Vienna. The façade is divided according to the function. The division public-private goes over into the division bottom-top. The glass façade of the three lower commercial floors is subdivided vertically through steel columns covered with ceramics. The bow windows between the columns are a further
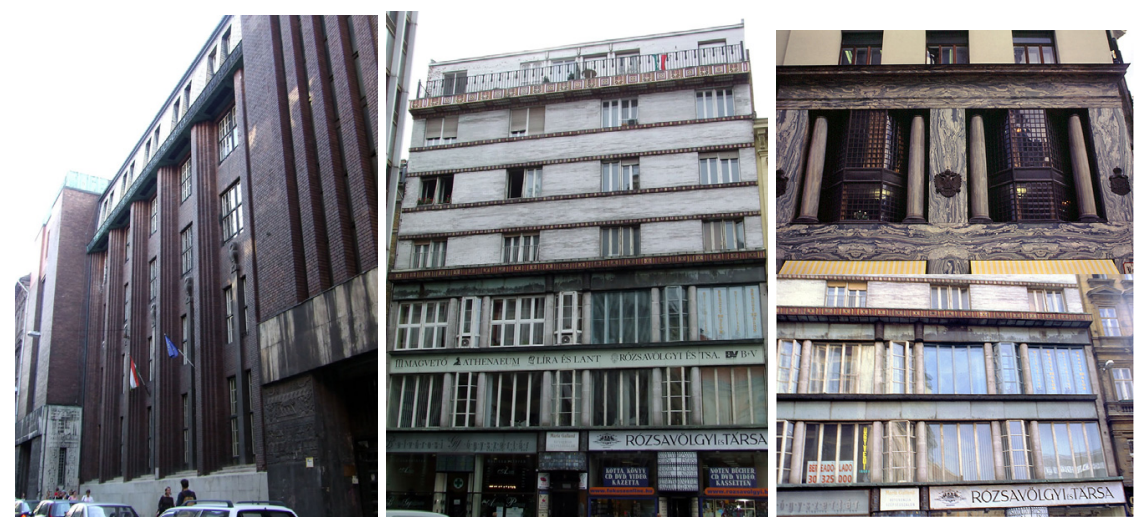

Figure 4: Turn-of-the century architecture of Béla Lajta: (a) Commercial School; (b) block of flats Rózsavölgyi; (c) comparison of the motifs of the latter with those in the Loos house at Michaelerplatz in Vienna. 
common feature with the Goldman and Salatsch building of Adolf Loos (Fig. 4(c)). The horizontal subdivision of the upper floors is a difference. The belt cornices are decorated with coloured folklore elements; the main cornice is the console like terrace closing in front of the set-back sixth floor. The construction is readable in the façade - that does not happen at the Loos house. However, in case of the Goldman and Salatsch building the Raumplan was first used for a great space configuration while the pretentious spatial shape of the Rozsavolgyi house was planned by another architect: Lajos Kozma, the head of the Budapest workshop. Like the Goldman and Salatsch building the Rózsavölgyi building aimed at a structure in reinforced concrete. The initial project foresaw a division of the structure in reinforced concrete and masonry according to the public-private registries (reinforced concrete in the lower floors and brick masonry at the upper floors), which, however, was not followed in the execution exactly. The plans published by [2] suggest the employment here of Hennebique floors.

In the neighbourhood of the Rózsavölgyi house is the former store Szenasy and Barczay (Fig. 5(a)). This store was built in 1909. This commercial building displays even more the neighbouring one of Lajta Viennaise influence. The bi-functional subdivision of the façade leads to different conformation of the upper and respectively lower three floors. The residential floors are covered with stone plates. The grid is emphasized as in case of Vágó and Wagner with visible steel nails. The commercial floors are widely covered with glass, with visible skeleton construction, with upper fields subdivided quadratically - the same influence of Fabiani, according to Moravánszky [1].
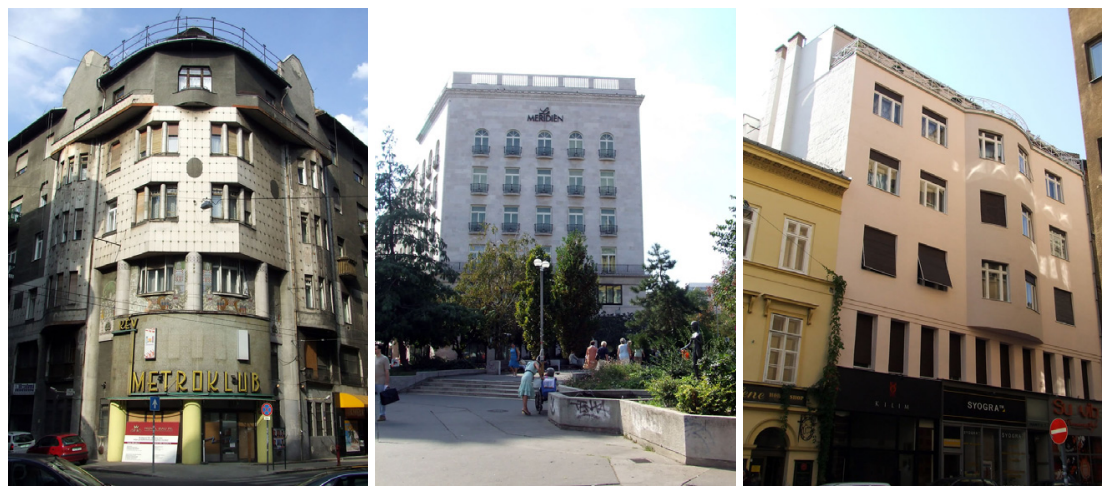

Figure 5: The façade of the block of flats in turn-of-the century Budapest: (a) József Vágo Arkadia basar; (b) Töry and Pogány Adria insurance building; (c) housing by Málnay and Haász on Irány Street.

Arkadenbasar (Fig. 5(a)) in Dohány Str. 22-24, by József Vágó, built in 1908, about which it is special that it stays the closest to the style of Otto Wagner in the Hungarian Secession. The decorative elements are cubistic, and Vágó displays 
enthusiasm towards the technical aesthetics as machine aesthetics. The rhythm of the façade comes from the ceramic nails fixings the ceramics plates. The ship shape at the corner marks the entrance. The side façades have the dynamic of waves, counterpointed by a non-interrupted balcony at the last level.

The insurance building of the society ADRIA, by Töry and Pogány, 1913 (Fig. 5(b)) displays, a corner solution coming from the blowing up of spatial limits of the Art Nouveau, as displayed by Palais Stoclet of J. Hoffmann (1911) [1].

A block of flats of Málnai and Haász on Irány Street in Budapest, built in 1912 (Fig. 5(c)) displays the English influenced Puritanism of Málnay (according to Moravánszky [1]). The façade is lacking ornaments, is covered with stone and the upper three floors are connected in the middle axis with a bow-window.

The building by architect Béla Lajta on Népszinház Street in Budapest, built in1911 (Fig. 6(a)) is an example of plastical shaping of the construction volume. Instead of shaping the elements, the construction as a whole was shaped. This effect, the new possibilities of architecture of big shaping instead of ornaments will be followed after the war. The play with the volume seems to be most suitable for reinforced concrete [1] but it is not. The state of the building allows it to see that it is a masonry construction with iron joists floors.
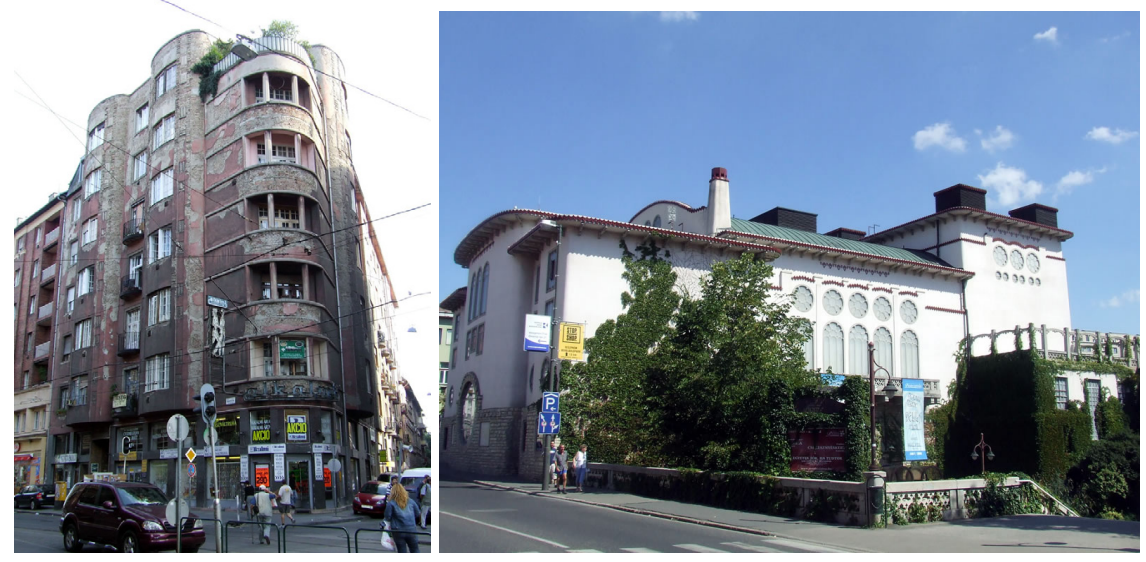

Figure 6: The approach towards reinforced concrete: (a) block of flats on Népszinház Street (B. Lajta); (b) theatre in Veszprém (I. Medgyaszay).

The theatre in Veszprém, architect István Medgyaszay was built in 1908. It is a multifunctional hall for the small city Veszprém. The auditorium is $20 \times 16 \mathrm{~m}^{2}$ big [1]. Although the first plans of the theatre in Veszprém were done during his stay in Paris, no traces of the French reinforced concrete architecture can be seen [1]. Moravánsky [1] reports that the theatre space is over spanned with a double shell construction. The interior cement shell of the auditorium consists out of decorative reinforced concrete grids for the aerial heating and is hanged on an 
extremely thin tubformed reinforced concrete construction between T-profiles out of iron. The solution introduced in case of the theatre of Veszprém was through that revolutionary and extremely economical. The window constructions out of reinforced concrete grids with glued glass panels, which did not need to be opened due to air conditioning are only a few of his new patents. In his lecture about the artistic solution of the iron concrete construction [3] BenkoMedgyaszay expresses also some thoughts about the separation between construction and space delimitation. The structuring elements of the building have to be shaped according to this valuation. For this he accentuated the surface character of the horizontal separation elements. But, according to Moravánsky [1], important for the history of architecture was the effort to characterise overall the special resistance states of the new material and to find an artistic shape language for reinforced concrete. The almost brutally appearing precast reinforced concrete ceiling which appears in the foyer, the penetrated concrete grids used for the first time, the decorative concrete window constructions with glued glass define the formal consequences of a house cast out of concrete. What is new and important for the theatre, was also formulated in the lecture. The whole building is, except of a part of the walls, out of reinforced concrete. Medgyaszay saw also the artistic relativeness of the iron concrete with timber [3]. The national style was not foreign to Medgyaszay. He also built other reinforced concrete buildings, characterised by a broken through shape of cornices.

Some aspects relevant for the shape of the building in Népszinház utca appear also in case of the much better known Einstein tower. We also remark, reviewing the literature, that the roots for the approach towards reinforced concrete comes from the Art Nouveau movement.

Huse [4] quoted Mendelsohn about the non-employment of reinforced concrete: "the formwork should have been done by ship constructors". This was observed later on also by Hilberseimer, quoted by Huse, that the shape of the Einstein tower does not correspond to the laws of construction in concrete. In this approach he is not alone: he sees, so Huse, the anticipation of reinforced concrete architecture in the works of Ernst Maria Olbrich, whose works in Darmstadt are illustrated, which were, however, built in timber and material. The next one quoted is Henri van de Velde, where he finds concrete in Jugendstil, as search for the shape, for morphology. The archive research of Huse finds enquiries from Mendelsohn asking for the dependence of the building shape not only from the function, but also from the material. Another theory on this subject known to us is that on tectonics theory of Frampton [5] Also Hoh-Slodczyk (in [4]) remarks the characteristic of the photos which inspires, through its monolithic shape and the uneven surface, the execution out of concrete, which spread in literature and was never contradicted by Mendelsohn. Also, so HohSlodczyk [4], the grey colour of photographs suggested concrete - contradicted by the fact that the tower was coloured. We wish to add that even as late as in 2006 we found the Einstein Tower presented as case of concrete construction at the fib international concrete congress in Naples 2006. So Mendelsohn in the letters so Hoh-Slodczyk [4] wishes a reinforced concrete construction, has, 
however, his doubts because of the lack of cement, and in later letters it is presented only as mixed construction, as it was constructed at the end: the lower part of the building would have been in reinforced concrete, the tower itself in brick masonry. The research of Hoh-Slodczyk [4] goes further in analyzing the documents due to which the material for the execution changed from concrete to brick masonry: documents on costs estimations in both materials. Pichler affirms that Louise Mendelsohn spreads a theory that in the years after WWI there was not enough steel for the reinforcement. This, however, contradicts the use of steel for the Klein'sche floor - much more, in Germany when the Ruhr zone was in blossom, steel was much easier to find than reinforced concrete and it was common for the structure of modernist buildings [6]. Also Pichler (in [4]) gives the Mendelsohn quote given earlier in the book by Huse that for the formwork of the concrete ship buildings would have been necessary. Pichler develops further the idea that round shapes are possible in reinforced concrete, as Saarinen built the airport building in New York, but in a mathematically designed shape where formwork out of straight wooden boards was possible. We would like to suggest as further reading an article published after this book about the use of formwork in Gaudi's Sagrada Familia [7]. The deficiencies of the Einstein Tower are caused, so Pichler [4], by the fact that the technique was too new.

\section{Architecture in Transylvania}

At the turn-of-the-century Oradea was a blossoming city of remarkable economic power. Reinforced concrete was also used Oradea, although the architectural style used is rather under the influence of other parallel currents from the Budapester architecture. While Dezső Jakab and Marcell Komor (Fig. 7, 8, 9(a)) and László and József Vágó, born in Oradea (Fig. 10), also worked in Budapest,
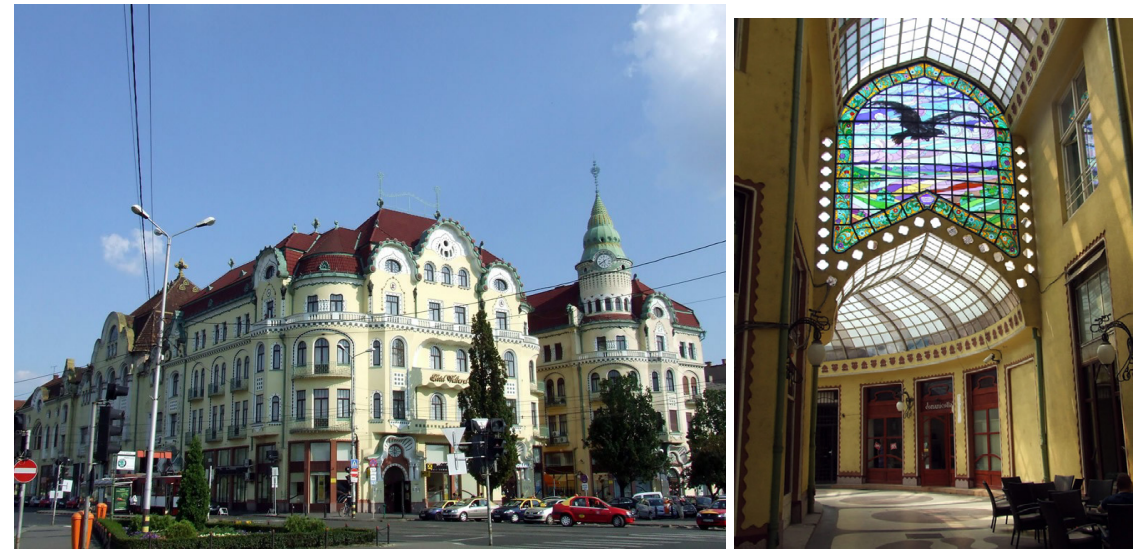

Figure 7: Vulturul Negru (Black Eagle) Palace (1907-09) Marcell Komor and Jakab Dezső inspired by Ödön Lechner. Note the stained glass. 


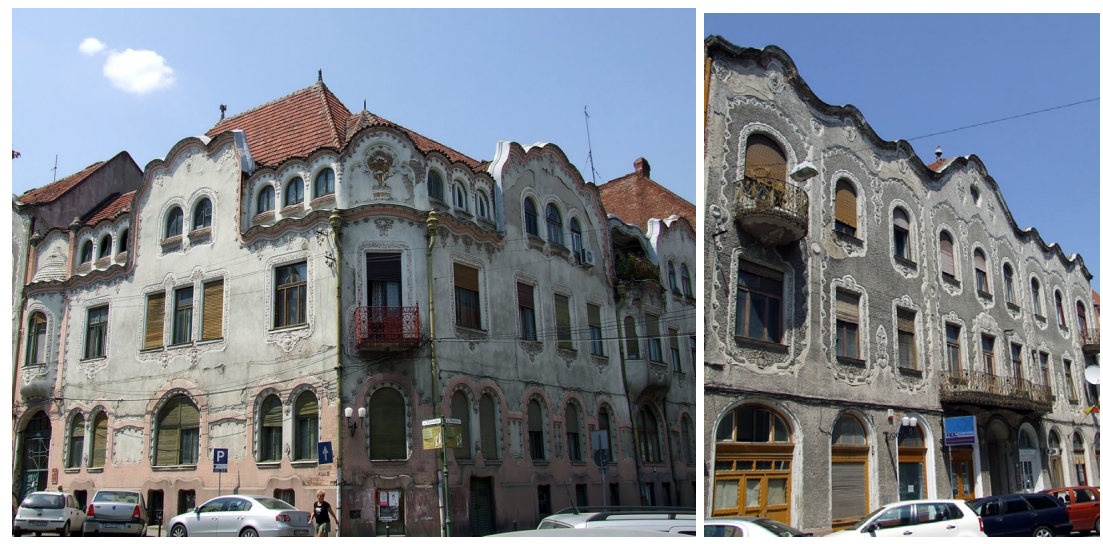

Figure 8: Adorjan houses (first houses in Oradea) Marcell Komor and Jakab Dezső, Patriotilor Street (a) I (1903), (b) II (1904-05).
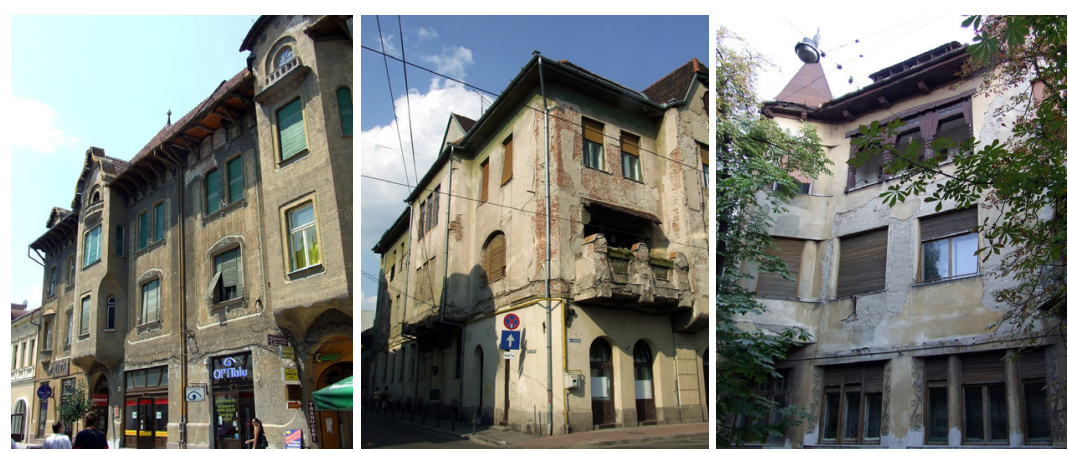

Figure 9: (a) Stern Palace (1904-05) Republicii 10-10A Marcell Komor and Jakab Dezső; villas by Valer Mende; (b) Villa Dr. Nemes (1909) Duiliu Zamfirescu 10; (c) Villa Ertler (1909), Episcop Mihai Pavel 8.
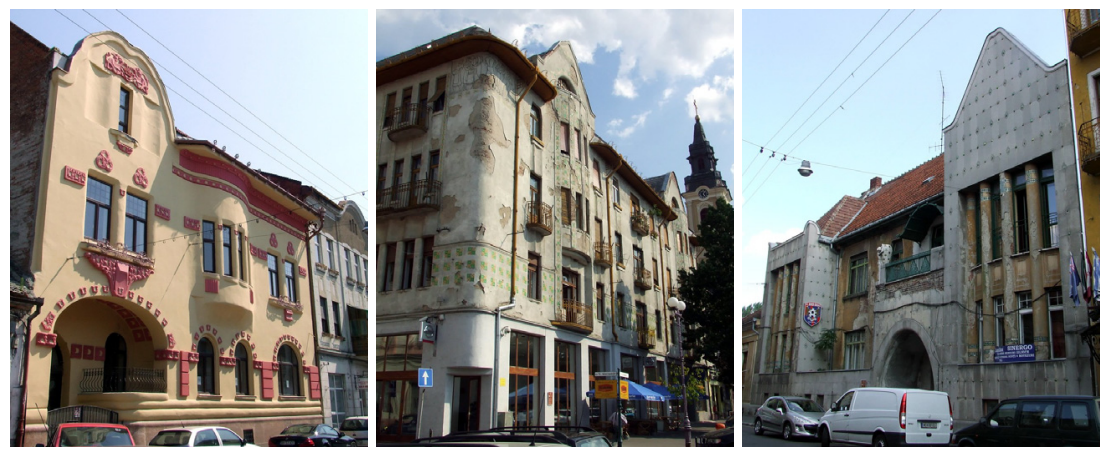

Figure 10: Buildings by József and László Vágo; (a) Villa Vago (1905), General Moşoiu 14; (b) Moskovits Palace (1910-11), Piaţa Unirii; (c) Villa Darvas-La Roche (1910-11), Vulcan Iosif 11. 
there were local architects such as Ferenc Sztarill (11(b) and (c)) and Kálmán Rimanóczy senior and junior (Fig. 11(a), 12) [8]. The Moskovits Palace (Fig. 12(b)) is the first one where such was used, in Hennebique system designed by eng. Zielinszky Szilárd from Budapest (Paşca [9]). Remarkable in the architecture of Oradea is the employment of stained glass windows [10], so specific for Art Nouveau, for example in Bruxelles. Glass was differently seen that time. Komor and Jakab also designed buildings for the centre of Târgu Mureş (Fig. 13). István Medgyaszay built some school buildings in Banat (Reşita, Caransebeş etc.). While the buildings are foreseen with plates in order to facilitate a cultural circuit, most of them need restoration, as the pictures show. Those already restored (villa Vágó) do not respect colour principles. Oradea is about to join the Réseau Art Nouveau Network [11], where Budapest is already member.

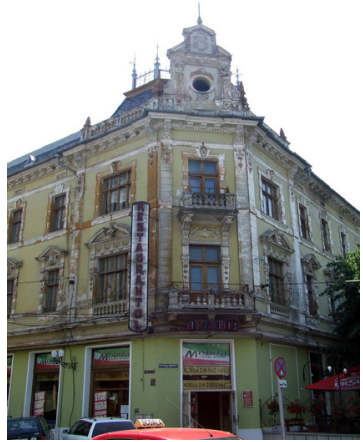

Figure 11: Local architects from Oradea: (a) Hotel Crişul Repede (Rimanoczy) (1891-92/1900) Libertăţii 8, Kálmán Rimánóczy sr.; Buildings by Ferenc Sztarill; (b) Poynar house (1907) Nicolae Grigorescu 6; (c) Hotel Astoria (Sztarill Palace) 1902 (ext. 1906), Teatrului 1.
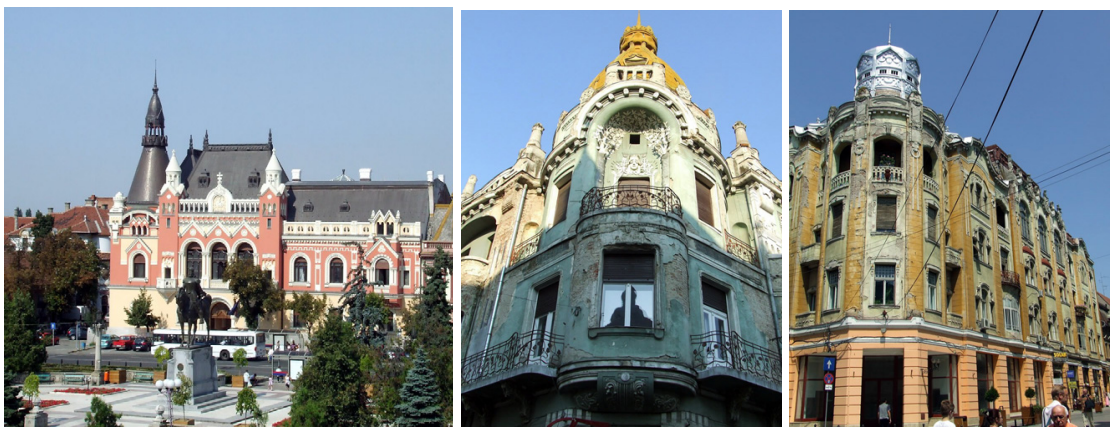

Figure 12: Buildings by Kálmán Rimánoczy jr. (a) Greek-Catholic Episcopal palace (1903-05), Piaţa Unirii 3, Ep. M. Pavel 1; (b) Moskovits Miksa Palace (1904-05), Parcul Traian nr. 2, (first building with reinforced concrete); (c) Apollo Palace (1912-14), Republicii 12. 

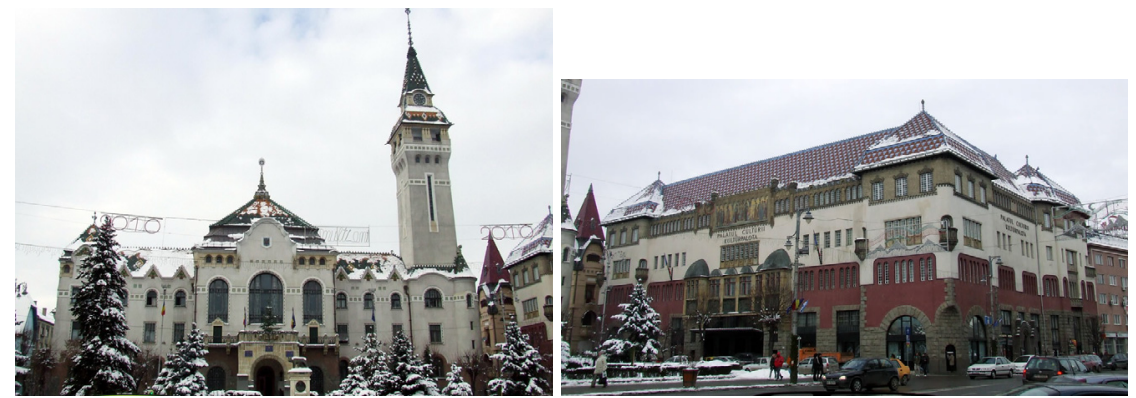

Figure 13: Centre of Târgu Mureş, Marcell Komor and Jakab Dezsó (a) Prefectura Judeţului (1906-07); (b) Culture Palace (1911-13).

\section{Discussion and conclusions}

This paper presents the interdependence between the architectural form and structural language, exemplified for historic reinforced concrete, in the architecture of Budapest at the turn of the century. The approaches in the house in Népszinház Street by Béla Lajta and the theatre in Veszprém exemplify the use of historic reinforced concrete in turn-of-century architecture of the Hungarian architects. Also the architect Károly Kós, whose work in Budapest has already been mentioned is one of the most notable architects from Transylvania (Fig. 14), with an original style which influences until today, along with Ödön Lechner the organic architecture of world class architect Imre Makovecz. A novelty in Makovecz's work is the introduction of reinforced concrete columns resembling wood [12] as well in the church in Százhalombatta, Hungary (Fig. 15(a)), and, as such, resembling the mentioned theories of
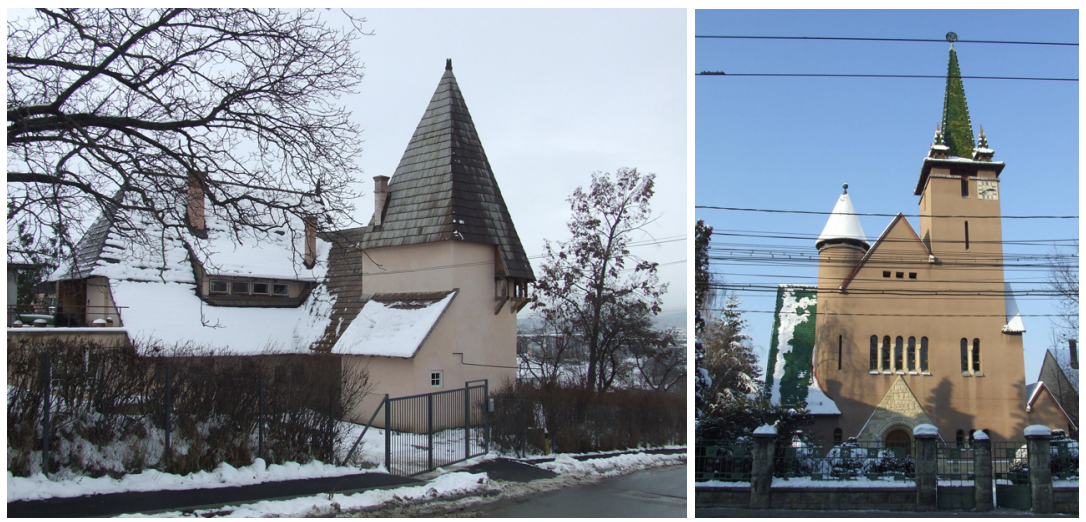

Figure 14: Károly Kós (a) house in Brétfü Street (Utilitas headquarters); (b) Reformed church (church with cock) Calea Moţilor 84 19131914. 
Medgyaszay regarding a language for reinforced concrete. Although reinforced concrete was one of the "new" materials introduced by the Modern Movement, the Hennebique system was used well before, also in turn-of-the-century time. In this time the architectural expression was not necessarily fitting the new material, as there was still use of decorations from brick architecture. Approaches in Hungary are typical for early approaches, either at the level of the study of the shape (Béla Lajta in Népszinház Street) or at theoretical approach regarding the need of a language (Medgyaszay).

These theoretical approaches regard the dialogue between the language of the timber and that of reinforced concrete, a dialogue which continues until today. One must only think of the interpretation of the skeleton structure of timber versus reinforced concrete in earthquake zones (Langenbach [13]).

But the approach Hungarian architecture has is different: it regards the monumental structures of large span spaces as in theatres and churches. Following the theoretical approach of Medgyaszay today Makovecz employed the language of timber in reinforced concrete in the church of Százhalombatta, different from his usual timber organic architecture: trees out of reinforced concrete. The approach is not singular in contemporary architecture: the gothic shapes employed by Santiago Calatrava in his railway station design (ex. Oriente railway station, Lisbon, Fig. 15b) remind the way trees are bearing weight, in an organic approach as well. There is still need to learn from spatial structures to the multi-storey skeleton structures of Langenbach [13].
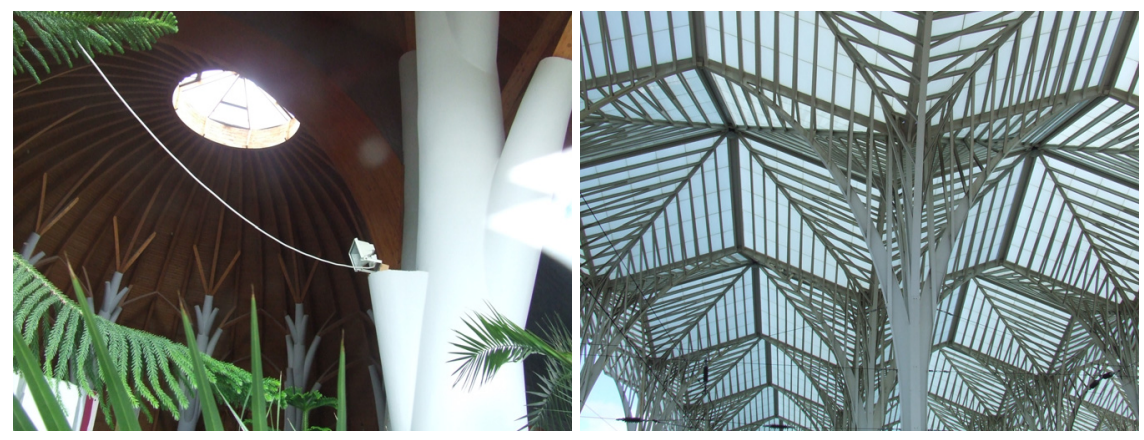

Figure 15: (a) Roman Catholic church, Százhalombatta (1996-98), Imre Makovecz; (b) Oriente Station, Lisbon (1993-98) Santiago Calatrava.

\section{Acknowledgements}

Photographs of buildings in Budapest: Maria Bostenaru, 2006-2007 (Grant CA'REDIVIVUS). Photographs of buildings in Oradea, Târgu Mureş and Cluj: Maria Bostenaru, 2009. Photographs in Százhalombatta and Lisbon Maria Bostenaru, 2010 (Grant PIANO). Both grants from the European Commission, as Marie Curie Fellowships. Participation in STREMAH 2011 - acknowledgements to Wessex Institute of Technology, UK. 


\section{References}

[1] Moravánszky, Á., Die Architektur der Jahrhundertwende in Ungarn und ihre Beziehungen zu der Wiener Architektur der Zeit, Verband der Wissenschaftlichen Gesellschaften Österreichs: Vienna, 1983.

[2] Csáki, T., Lajta Béla Virtuális Archívum http://lajtaarchiv.hu/

[3] Benko-Medgyaszay, I., Über die künstlerische Lösung des Eisenbetonbaues. In: Berichte über den VIII. Internationalen Architektenkonge $\beta$ Wien 1908, Wien, 1909, pp.538ff.

[4] Huse, N. (ed.), Mendelsohn - Der Einsteinturm. Die Geschichte einer Instandsetzung, Karl Krämer Verlag: Stuttgart + Zürich, 2000.

[5] Frampton, K., Studies in Tectonic Culture. The Poetics of Construction in Nineteenth and Twentieth Century Architecture, MIT Press: Cambridge, 1995.

[6] Bostenaru Dan, M., Prefabricated metal construction of the Modern Movement, in World Housing Encyclopedia- summary report 2004, ed. Brzev, S., Greene, M., EERI: Oakland CA, 2004, report \#95.

[7] Gómez-Serrano, J., Espel, R., Grima, R., Burry, M. C., Aguadoa, A., Evolution of the Formwork Used in the Temple of the Sagrada Familia, International Journal of Architectural Heritage, 3(2), pp. 93-109, 2009.

[8] Paşca, M., Habitatul oradean la inceputul secolului al XX-lea, Editura Universitatii din Oradea: Oradea, 2008.

[9] Paşca, M., Palatul Moskovits Miksa, Oradea, http://enciclopedie.transindex.ro/monument.php?id=313, 2010.

[10] Hârcă, R., Vitralii 1900 http://www.cimec.ro/monumente/vitralii/home.htm

[11] Réseau Art Nouveau Network http://www.artnouveau-net.eu/

[12] Makovecz, I., Százhalombatta, Roman Catholic Church http://www.makovecz.hu/28.html

[13] Langenbach, R., From "Opus Craticium" to the "Chicago Frame": Earthquake-Resistant Traditional Construction, International Journal of Architectural Heritage, 1(1), pp. 29-59, 2007. 